\title{
LIMITS OF AUTONOMY PRINCIPLE IN DOCUMENTARY LETTERS OF CREDIT; PERSPECTIVE OF ENGLISH LAW
}

\author{
Lecturer Hamed Alavi, PhD Candidate ${ }^{1,2}$ \\ ${ }^{1}$ Tallinn Law School, Tallinn University of Technology, Estonia \\ ${ }^{2}$ Autonomous University of Barcelona, Spain
}

Hamed.alavi@ttu.ee

(Received December 2016; Accepted March 2017)

\begin{abstract}
In this article, the author reviews the approach of English courts to limits of autonomy principle and tries to answer the following research questions: What obligations should the applicant fulfil while opening a credit in accordance with the underlying contract? What are the seller's remedies when the buyer fails to perform his duties regarding opining and performance of the credit? On the other hand, what are the seller's duties in the process of opening the credit and what will be the buyer's remedy in case of his failure? What is the legal position regarding variation of the credit? What is the position of court regarding absolute or conditional nature of the credit? In order to answer the above research questions, paper is divided into seven parts: after the introductory comments, the second part will review the nature of the buyer's obligation in opening the credit. The third part is focused on effect of non-compliance by the buyer and the fourth part studies the variation of the credit and its effect on party's rights within the underlying contract. Part five deals with the buyer's rights after opening the credit while part six will discuss the absolute or conditional nature of the payment obligation to pay under the LC. Last but not the least, the final part will provide some concluding remarks.
\end{abstract}

Key Words: Documentary Letters of Credit, Autonomy Principle, Limits, English Law

\section{Introduction}

Letters of credit used in international trade finance are governed by two fundamental principles of autonomy and strict compliance (Alavi 2015). While the principle of strict compliance provides guarantee for the beneficiary to be paid after presenting the bank with compliant documents to the terms and conditions of the credit, the principle of autonomy separates undertaking of the bank to honour the beneficiary's presentation from performance of the underlying contract. As a result, any disputes in the framework of the contract between buyer and seller or between the issuing bank and applicant should be reviewed separately from issues relevant to performance of the credit per se (Alavi, 2016e). In practice, the principle of autonomy implies that any failure of beneficiary to comply with his obligations in the underlying contract and delivery of goods with promised quantities or quality will neither affect bank's obligation to pay him after receiving complying presentation nor applicants' obligation to reimburse the issuing bank which has honoured a complying presentation (Alavi, 2016b). Therefore, "pay first and argue 
later" is an accepted outcome of autonomy principal's application in international LC operation (Eakinv, 1989). It is possible to conclude that the autonomy principle promotes the international trade by safeguarding the smooth operation of documentary letters of credit (Alavi, 2016d, Alavi, 2016c). As a result, the autonomy principle is the "cornerstone of the validity of the letter of credit" (Ward Petroleum Corp. v. Federal Deposit Ins. Corp., 903 F.2d 1299, 1990) and "the engine behind the letter of credit" (Arkins, 2000).

The operation of the letters of credit is governed by globally recognized sets of rules introduced by the International Chamber of Commerce (Alavi, 2016a). Published for the first time in 1933, Uniform Customs and Practices for Documentary Credits (UCP) have been revised constantly in order to comply with THE evolving trade requirements and technology developments in the field of international trade. Principle of autonomy is shrined in Article 4 and 5 of UCP 600 (current version) as following:

"A credit by its nature is a separate transaction from the sale or other contract on which it may be based. Banks are in no way concerned with or bound by such contract, even if any reference whatsoever to it is included in the credit. Consequently, the undertaking of a bank to honour, to negotiate or fulfil any other obligation under the credit is not subject to claims or defences by the applicant resulting from its relationships with the issuing bank or the beneficiary" (UCP600-Article 4)."

"A beneficiary can in no case avail itself of the contractual relationships existing between the banks or between the applicant and the issuing bank. An issuing bank should discourage any attempt by the applicant to include, as an integral part of the credit, copies of the underlying contract, proforma invoice and the like. Finally, banks deals with documents and not with the goods, services or performance to which the document relate" UCP600Article 5)."

The United States of America ARE the only country which have regulated operation of documentary letters of credit in national statutory format. Article 5 of Unified Commercial Code. Article 5 - 103(d) of UCC formulates the autonomy principle as follows:

"the rights and obligations of an issuer to a beneficiary or a nominated person under a letter of credit are independent of the existence, performance, or non-performance of the contract or arrangement out of which the letter of credit arises or which underlie it, including contracts or arrangements between the issuer and the applicant and between the applicant and the beneficiary"

Also, article 5-108(f) (1) confirms: 
Alavi H. (2017)

Limits of Autonomy principle in documentary letters of credit. Perspective of English Law

"[a]n issuer is not responsible for the performance or non-performance of the underlying contract, arrangement or transaction"

From the above discussion, it might seem that the autonomy principle applied in the process of financing international operations has an absolute fashion and the credit is completely separated from the underlying contract which gives reason to its existence. In fact, the existing body of English authorities indicates a completely contradictory reality. Unlike customary belief that performance under the credit has nothing to do with performance in the underlying contract, there are many conditions under which these two separate contracts show substantial overlap. Such overlaps show borders and limits of the principle of autonomy which are not reflected in UCP. Therefore, national laws are supposed to resolve disputes of this kind but, the diversified nature of national laws createS difficulty for learned observers to reach legally sound conclusionS about situations under which the performance of the credit depends on the performance of the underlying contract. For the purpose of reducing confusion, in this article, the author reviews the approach of English courts to limits of the autonomy principle and tries to answer the following research questions: What obligations should the applicant fulfil while opening a credit in the framework of the underlying contract? What are the seller's remedies when the buyer fails to perform his duties regarding opining and performance of the credit? On the other hand, what are the seller's duties in the process of opening the credit and what will be the buyer's remedy in case of his failure? What is the legal position regarding variation of the credit? What is the position of court regarding absolute or conditional nature of the credit? In order to answer the above research questions, the paper is divided into seven parts: after the introductory comments, the second part will review the nature of the buyer's obligation in opening the credit. The third part is focused on effect of noncompliance by the buyer and the fourth part studies variation of the credit and its effect on party's rights within the underlying contract. Part five deals with the buyer's rights after opening a credit while part six will discuss absolute or conditional nature of the payment obligation to pay under the LC. Last but not the least, the final part will provide some concluding remarks.

\section{The nature of the buyer's obligation to open the credit}

In the framework of international trade, as a general rule, letters of credit come to existence when a buyer (applicant) and seller (Beneficiary) agree in their underlying contract for the payment to be arranged by opening of the credit. Incorporation of the letter of credit clause in the contract of sales (or any other agreement between parties) will impose a duty on applicant to procure the credit in favour of the beneficiary. Under English law, depending on stipulations in the underlying contract, the existence of the applicant's duty to open a credit can bring 
about different legal consequences which are covered in relevant authorities. In Trans Trust S. P. R. L. v. Danubian Trading Co. Ltd., where the buyer failed to open a credit as stipulated in the underlying contract of sales, Denning L.J observed:

"What is the legal position of such a stipulation [that a credit should be provided]?

Sometimes it is a condition precedent to the formation of a contract, that is, it is a condition which must be fulfilled before any contract is concluded at all. In those cases the stipulation 'subject to the opening of a credit' is rather like a stipulation 'subject to contract'. If no credit is provided, there is no contract between the parties. In other cases a contract is concluded and the stipulation for a credit is a condition which is an essential term of the contract. In these cases the provision of the credit is a condition precedent, not to the formation of the contract, but to the obligation of the seller to deliver the goods. If the buyer fails to provide the credit, the seller can treat himself as discharged from any further performance of the contract and can sue the buyer for damages for not providing the credit".(Trans Trust S.P.R.L. v. Danubian Trading Co. Ltd [1952] 2 Q. B. 297)

Todd differentiates consequences of conditions explained by Denning L.J in two different situations: in previous seller and buyer are both exempt from obligation under the contract where no letter of credit has been procured. However, in the latter situation, the buyer will be liable for damages where the seller is relieved from his obligations in the underlying contract (Todd, 2013).

There are lines of authorities and academic opinions in favour of the above mentioned observation. Benjamin explains that buyer's obligation to open a credit in favour of the seller may not be condition precedent for all responsibilities of the seller; however, it is condition precedent for delivery of goods (Guest, 1997, Tiplady, 1989). There are certain conditions considered as condition precedent for buyer's obligation to open the LC in favour of the Seller. In Knotz v. Fairclough, Dodds and Jones Ltd, which was relevant to sales of copra, issuing a proforma invoice by seller was a condition precedent for buyer to open the credit in his favour. As a result of seller's failure to issue the proforma invoice, the court ruled in favour of buyer by holding that:

"The buyers' obligation to provide a letter of credit did not arise until a provisional invoice was tendered by sellers and proper notice given by him as to the form of credit he required" (Knotz v. Fairclough, Dodds and Jones Ltd. [1952] 1 Lloyd's Rep 226).

Ventris differentiates legal consequences of the situation where the buyer agrees to pay the price of the underlying contract directly to the seller from situation under which he agrees to procure a credit in favour of the seller (Ventris, 1975). As a 
result, in the latter condition obligations of the buyer in contract with seller will be fulfilled where he opens a credit in favour of seller which conforms to requirements stipulated in the underlying contract.

\subsection{Cooperation of Buyer in process of operation of the LC}

With respect to the terms of the underlying contract, the credit might require buyer's cooperation in operation of credit's (Ellinger, Neo, 2010). This can be the situation under which the buyer is supposed to nominate the vessel (e.g. in case of classic FOB contracts). Without cooperation of the buyer, in nominating the vessel, the seller will not be able to perform his duty in the contract of sales and in case no nomination of vessels takes place, the buyer is the one to be liable for breach of contractual obligations (Malek, Quest, 2009). Such collaboration might be in two forms: first, the buyer informs the bank about nomination of the vessel. Therefore, the bank will effectuate payment where shipping documents show the shipment on the nominated vessel. The second situation is where the seller provides the bank with documents stipulating that the vessel is nominated by the buyer. (This was the requirement of credit in Banque de l'Indochine et de Suez SA v JH Rayner (Mincing Lan) Ltd. [1983] Q. B. 711)

Other circumstance which requires buyer's cooperation is where he agrees in the underlying contract to participate in completion of tender of documents under the credit. This might happen by signing the certificate of inspection by him or his representative. Buyer's failure to cooperate in fulfilment of his obligation under the credit will result in breach of his contract with the seller (Malek, Quest, 2009). The buyer might be obliged by court to cooperate and in case of his inability to cooperate a third party (a court official) will receive authority to take his place (Astro Exito Navegacion SA v Chase Manhattan Bank NA [1983] 2 AC 787).

\subsection{Type of the Credit to be Opened}

The type of documentary letter of credit which the buyer procures in favour of the seller should be in compliance (in form and substance) with the requirements in the underlying contract (Panoutsos v. Raymond Hadley Corporation [1917] 2 KB 473); Soproma S.p.A v. Marine and Animal By-Products Corporation [1966] 1 Lloyd's Rep. 367,386. ); Enrico Furst \& Co. v. WE Fischer Ltd. [1960] 2 Lloyd's Rep 340.).

In Wahbe Taman \& Sons Ltd. v. Colprogeca Sociedade Geral de Fibras. Cafes e Produtos Coloniais Lda, the contract of sales asked for opening of the confirmed credit. However, the correspondent bank reserved the right of recourse against the beneficiary. As a result, the court held the applicant liable for failure in providing 
the type of credit stipulated in the underlying credit. It might occur that the parties do not specify the type of credit in the underlying contract. In such situation, English courts incline towards presuming agreement of parties towards irrevocable credit to be provided (Benjamin's Sale of Goods, at $\S 23-066$ p. 1685). In Giddens v. Anglo African Produce Ltd, contract of sales required for "establishment" of credit with a defined bank. The issuing bank opened a revocable credit which resulted in refrainment of the beneficiary to deliver goods. In the hearing, Balihach, J. ruled in favour of the seller. ${ }^{1}$ Benjamin confirms the ruling of Bailhach $\mathbf{J}$ as judge "read the word 'established' as describing the word 'credit' and explained that the revocable credit furnished by the buyers could not be considered an 'established credit" (Benjamin's Sale of Goods, at § 23-066 p. 1685).

It should be kept in mind that the contract is not considered as concluded where nature of credit is not defined or tendering documents against payment are not determined (Malek, Quest, (2009). Therefore, no party will be liable as no consensus ad idiem has taken place.

\subsection{Time for availability of the credit}

Where the underlying contract provides payment to be done by documentary letters of credit, the buyer is obliged to provide the credit in time and he is liable even for delays resulted by factors out of his control (In Lindsay (AE) \& Co Ltd v Cook [1953] 1 Lloyd's Rep 328, where a delay was caused by the inter-bank communication, the seller was held entitled to repudiate the contract of sale.)

The underlying contract should contain information regarding time for availability of the credit. In absence of such information the courts will intervene in order to determine the reliance of the seller on the contract of sales and determine a reasonable time for the buyer in opening the credit (Todd, 2013). In the following lines we examine different scenarios which might occur in absence of a defined time to open the credit in the underlying contract. If the contract calls for credit to be opened immediately, the applicant should be given a reasonable time sufficient for a diligent person to establish the credit (Hedley, 1997) ${ }^{2}$. If the contract requires

\footnotetext{
${ }^{1}$ Bailhache J., in delivering judgment for the sellers said:

"Here is a contract which calls for an established credit and in purported satisfaction of what this contract calls for what they get is this: 'Negotiations of drafts under these credits are subject to the bank's convenience. All drafts hereunder are negotiated with recourse against yourselves.' How that can be called an established credit in any sense of the word absolutely passes my comprehension".

${ }^{2}$ Also regarding the determination of reasonable time, Porter J. in the hearing of Garcia v. Page \& Co Ltd (1936) [55 LI Rep 391]refers to test which was established by Lord Watson in the Judgment of Hick v. Raymond \& Reid [1893] A.C. 22:

"When the language of a contract does not expressly, or by implication, fix any time for the performance of a contractual obligation, the law implies that it shall be performed within a reasonable time. The rule is of general application, and is not confined to contracts for the carriage of goods by
} 
for credit to be opened in within few weeks, then reasonable time would be defined based on the nature of contracted goods which are subject to trade (Benjamin's Sale of Goods, at $\S 23-068$ p. 1685). If opening of the credit is conditioned upon seller to provide information about readiness of goods for shipment, it will be compulsory for buyer to open the credit immediately after receiving such information from seller (Ellinger, Noe, 2010). Under the situation where shipment is supposed to take place over a period of time, the credit should be opened within the whole period of time mentioned in the contract (Hedley, 1997).

Ambiguous clauses regarding the time for opening of the credit in the underlying contract can create problems. In the American case of Sohio Supply Co. v Gatoil (USA) Inc contract of sales required buyer to provide the credit 10 days before the time of loading. However, the problem occurred when the parties expressed different interpretations from the clause. The seller considered the time for opening of the credit 10 days from starting the voyage while the buyer based his calculations on the arrival day of the ship. In Staughton L.J supported the view regarding the seller's position by observing:

"I have no doubt that the sellers show a good arguable case on that point; I do not think it would be right for me to say more than that. That makes it unnecessary to consider whether the affidavit which they produced sufficiently displays a good arguable case on the point of custom" (Sohio Supply Co. v Gatoil (USA) Inc. [1989] 1 Lloyd's Rep 588.).

Another interesting case is Transpetrol Ltd. v. Transöl Olieprodukten Nederland $B V$ in which the buyer committed to open the credit one day after receiving notice of appointment of the ship. However, the problem arose where in the underlying contract, the seller agreed to give additional three days to buyer in the format of intention to nominate the vessel.

In the hearing Philips J. observed: "It seems to me that the concept of being required to give a minimum of three days' notice of intention to nominate is nonsensical.

Prima facie such a notice is of no value to the buyer for it is implicit that there is the intention to nominate in any event" (Transpetrol Ltd. $v$ Transöl Olieprodukten Nederland BV [1989] 1 Lloyd's Rep 309.).

The court ruled in favour of seller and held that seller had the right to repudiate contract of sales as a result of delay in opening the credit. (Transpetrol Ltd. $v$ TransölO lieproduktenN ederlandB V [1989] 1 Lloyd's Rep 309.)

sea. In the case of other contracts the condition of reasonable time has been frequently interpreted; and has invariably been held to mean that the party upon whom it is incumbent duly fulfils his obligations, so long as such delay is attributable to causes beyond his control, and he has neither acted negligently nor unreasonably" 


\subsection{Time for opening of credit under CIF contracts}

In the practice of international trade, most of the time CIF contracts specify the date or period of shipment without referring to time for opening the credit Malek, Quest, 2009). Since English law follows rational of entitles the seller to have access to credit before shipment of goods, in CIF contracts of sale which specify date of shipment, the buyer should open the credit at a reasonable time before that date (Plasticmoda Societa perAzioni v Davidsons (Manchester) Ltd. [1952] 1 Lloyd's Rep 537,538). However, parties may include different provisions in the contract which affect such obligation. For example, when parties agree that opening of credit will be subjected to receive particular instructions from seller, opening of the credit will depend on time of receiving such instructions from the seller and buyer's obligation will start immediately from the moment of receiving them (Nicolene Ltd v Simmonds [1952] 2 Lloyd's Rep 419, affd. [1953] 2 Q. B. 543).

When the underlying contract provides a period of shipment, then ambiguity will rise regarding the time for the buyer's obligation to furnish the credit. in such cases, english law does not have a clear position whether the credit should be furnished at reasonable time before shipment of goods or at first day of shipment (Malek, Quest, 2009).

In Pavia \& Co. S. p. A. v. Thurmann-Nielsen the contract of sales defined the period of shipment between February to April 1949, but the credit was opened on April 22. Denning L.J observed that: in absence of express stipulation, beginning of shipment period is time for opening the credit "because the seller is entitled, before he ships the goods, to be assured that, on shipment, he will be paid. The seller is not bound to tell the buyer the precise date when he is going to ship; and whenever he does ship the goods, he must be able to draw on the credit. He may ship on the very first day of the shipment period". (Malek, Quest, 2009) There is the possibility to consider two conditions from Denning L.J's observation: One is, the first day of shipment is the latest time for furnishing the credit. Second, since the seller is entitled to have assurance about payment before dispatch of goods, the latest date for furnishing the credit is a reasonable time before commencement of shipment (Benjamin's Sale of Goods, at § 23-069 p. 1686; Chorley, Smart, 1990). In Sinason-Teicher Inter-American Grain Corporation v. Oilcakes and Oilseeds Trading Co. Ltd contract of sales considered shipments of barely between October to November 1952, the seller cancelled the contract on 10th of September due to failure of buyer in providing the bank guarantee. Supporting the second view, Lord Denning said: "The correct view is that, if nothing is said about time in the contract, the buyer must provide the letter of credit within a reasonable time before the first date for shipment. The same applies to a bank guarantee" (Sinason-Teicher 

[1954] 1WLR 1394.).

\subsection{Time for opening of credit under FOB contracts}

Although in some variations of the FOB the contract seller will make the shipping arrangements, in general, such type of contracts provide the buyer with the possibility to define the date of shipment (Malek, Quest, 2009). In the case of Ian Stach Ltd. v, Baker Bosley Ltd where the terms of sales were set as FOB contract, Lord Diplock rejected the view that the letter of credit should be opened at reasonable time before nominating the vessel by the buyer and set the first day of shipment period as the last date for furnishing the credit by buyer. (Ian Stach Ltd. v Baker Bosley Ltd [1958] 2 Q. B. 130) ${ }^{1}$

\section{Effect of non-compliance by the buyer}

\subsection{Seller's right to terminate the underlying contract}

In the practice of international trade, the seller is entitled for withholding goods until the complying credit with terms of underlying contract has been furnished by buyer. In case of buyer's failure to open the credit (upon specified date or within the framework of reasonable time), the seller has the right to terminate the contract (Malek, Quest, 2009; Ellinger, Dora, 2010). However, it should be kept in mind that English law only entitles the seller to terminate the contract after serving the buyer with a due notice of intention to terminate (Malek, Quest, 2009; Ellinger, Dora, 2010). In the notice, the seller should notify the buyer with precise deadline for opening the complying credit. As a result of the buyer's failure to open the credit on time, the seller will be fully entitled to repudiate the contract and claim for damages from the buyer. (Malek, Quest, 2009; Ellinger, Dora, 2010) In British and Commonwealth Holdings plc v. Quadrex Holdings Inc, Sir Nickolas BrowneWilkinson observed that: "where, if a time for completion had been specified in the contract, time would have been of the essence, the innocent party can make time of the essence by serving a reasonable notice to complete even though the guilty party has not been guilty of improper or undue delay" (British and Commonwealth Holdings plc v. Quadrex Holdings Inc [1989] Q. B. 842). Jack justifies the seller's right for repudiation under English law by pointing at buyer's privilege to open a credit within a specified period of time. Therefore, THE seller should hold the right

\footnotetext{
${ }^{1}$ He commented: "the buyer would not know how long it would take to bring the goods from the place where they were and transport them to the port: he would not know in a case of this kind, and did not know, whether or not the goods had to be rolled to order or whether they were in stock or whether they were partly rolled. It seems to me that in a case of this kind, and in the case of an ordinary f. o. b. contract financed by a confirmed banker's credit, the prima facie rule is that the credit must be opened at latest... by the earliest shipping date"
} 
Limits of Autonomy principle in documentary letters of credit. Perspective of English Law

to end the contract if buyer's behaviour at the end of that period is a sign of his repudiation (Malek, Quest, 2009).

\subsection{The seller's remedies against the buyer's failure}

The seller is fully entitled to damages against the buyer under the circumstances in which failure of buyer to open a complying letter of credit is reason for nonperformance of the contract (Heisler v Anglo-dal Ltd. [1954] 2 All ER 770.; Schmitthoff, 1990) p. 421). The legal basis for assessment of damages will be the same as the situation in which the buyer is found liable for rejecting the contract. (Malek, Quest, 2009) Damages will be assessed via reduction of contract price of goods from their market price (Sale of Goods Act 1979, s. 50). In Ian Stach Ltd. v Baker Bosley Ltd; sellers were rewarded with difference of the contract price and the market price of goods, which they have received by re-selling them. It is also held that if buyers become aware of some particular information during the conclusion of the contract of sales, measures for estimation of their liability for damages while failing to open the credit on time will be different (Trans Trust SPRL v Danubian Trading Co Ltd [1952] 2 Q. B. 297.). In Trans Trust SPRL v Danubian Trading Co Ltd buyers already knew that failure to open the credit on time will prevent sellers from procuring the essential materials required under the contract of sales (Trans Trust SPRL v Danubian Trading Co Ltd [1952] 2 Q. B. 297.) Therefore, plaintiff sellers were awarded with "a sum equal to the profit which they would have made if the credit had been opened and the successive sales had gone through" (Trans Trust SPRL v Danubian Trading Co Ltd [1952] 2 Q. B. 297.).

\subsection{Buyer's failure to open the credit on time or provide solvent paymaster}

Since sellers use the credit as a meanS of collecting finance, documentary letters of credit involved in the practice of international trade are considered more than just a method of payment for the price stipulated in the underlying contract. Therefore, buyer's failure to open the credit will make him liable to breach of contract and make sellers entitled to damages under principles of the contract law. In the case of Trans Trust S.P.R.L. v. Danubian Trading Co. Ltd (Trans Trust SPRL v Danubian Trading Co Ltd [1952] 2 Q. B. 297.) where the underlying contract covered sales of steel, buyers failed to open the complying credit with terms and conditions of the contract. Subsequently, sellers claimed for loss of profit which they could gain from the sales process. In response, buyers argued that sellers could re-sale goods as market was rising (Trans Trust SPRL v Danubian Trading Co Ltd [1952] 2 Q. B. 297.). Sellers replied that they were relying on credit to finance their transaction and in fact, due to buyer's failure to open the credit it was not possible for them to 
sell the steel which they did not buy from the manufacturer ${ }^{1}$. Same principles will be in place while calculating damages in the falling market. In Ian Stach Ltd. v. Baker Bosley Lts, after considering sellers' right in repudiation of contract due to failure of buyers to furnish the credit on time, Lord Diplock J, explained that sellers are entitled to damages which are measured based on the difference between the contract price and the price of goods at the time of repudiation (which he considered as loss of profit for sellers due to falling market). (Ian Stach Ltd. v Baker Bosley Ltd [1958] 2 Q.B. 130.)

In Urquhart Lindsay \& Co. v. Eastern Bank Ltd., the underlying contract covered sales of machinery by instalmentS in accordance with the number of shipments which were supposed to deliver the goods. The buyer paid two instalments after recovering the respective shipments. However, they ordered the bank not to pay the instalment relevant to the third shipment. The sellers sued for damages and the question arose about the amount of damages. Rowlatt $\mathrm{J}$ concluded that trading by instalments entitles sellers to cancel the entire contract. Therefore, sellers were able to repudiate the entire contract on the basis of failure of buyer in payment of one instalment and their claim on damages would be calculated on the basis of damages in the entire transaction. (Urquhart Lindsay \& Co. v. Eastern Bank Ltd [1922] 1 K. B. 318.)

In summary, the buyer would be in breach of the underlying contract while failing to open the complying credit or when the credit fails to operate properly. It is also worth mentioning that failure in opening or operation of credit is not a simple shortcoming in the payment for the price of goods. As credit is used by the seller in financing his activities, therefore, it means much more than a simple method of payment. According to Todd: "the damages are not limited to the payment of the price, but will be anything that is recoverable under ordinary principles applicable to contractual damages" (Todd, 2013).

\footnotetext{
${ }^{1}$ Denning L. J. in Trans Trust SPRL $v$ Danubian Trading Co Ltd about treating the provision of the credit as simply an alternative way of paying the price, said:

"This argument reminds me of the argument we heard in Pavia \& Co. v. Thurmann- Nielsen It treats the obligation to provide a credit as the same thing as the obligation to pay the price. That is, I think, a mistake. A banker's confirmed credit is a different thing from payment. It is an assurance in advance that the seller will be paid. It is even more than that. It is a chose in action which is of immediate benefit to the seller. It is irrevocable by the banker, and it is often expressly made transferable by the seller. The seller may be relying on it to obtain the goods himself. If it is not provided, the seller may be prevented from obtaining the goods at all. The damages he will then suffer will not in fact be nominal. Even if the market price of the goods has risen, he will not be able to take advantage of the rise because he will not have any goods to resell. His loss will be the profit which he would have made if the credit had been provided. Is he entitled to recover that loss? I think he is [subject to the normal rules of remoteness of damage in contract]..."
} 
Limits of Autonomy principle in documentary letters of credit. Perspective of English Law

4. Variation of the credit and its effect on party's rights within the underlying contract

\subsection{Amendment of the credit}

Amendment is an agreed variation of credit which takes place with the consent of all parties involved in the credit. Generally, the amendment is initiated by the applicant's request either with consent or upon request of the beneficiary (Jack 56). In practice, the amendment will be carried out in between the beneficiary and the issuing bank and most probably it will involve advising bank which will be discussed in following section.

\subsubsection{Legal position}

The documentary letter of credit is a binding guarantee undertaken by the issuing bank in favour of the beneficiary. Similar to the contract which can be changed only after consent of all parties, the credit can be amended only with agreement of the issuing bank and the beneficiary seller. Consent of advising the bank would be required where it is supposed to confirm the credit. Agreement of the buyer is impliedly necessary (though applicant is not a party to the credit) as both credit and amendment are issued based on his initiative (Rosenblith, 1987). There are many reasons for initiating an amendment to a credit including: unhappiness of the beneficiary with the terms and conditions of the credit, the seller's need for extension of shipping time or changing the type of credit.

Article 7 and 8 of the UCP 600 define responsibilities of the issuing and confirming bank and article 10 covers relevant legal aspects of issuing as well as amending the credit. ${ }^{1}$

\footnotetext{
${ }^{1}$ UCP 600, Article 10 Amendments:

"a. Except as otherwise provided by article 38, a credit can neither be amended nor cancelled without the agreement of the issuing bank, the confirming bank, if any, and the beneficiary.

b. An issuing bank is irrevocably bound by an amendment as of the time it issues the amendment. A confirming bank may extend its confirmation to an amendment and will be irrevocably bound as of the time it advises the amendment. A confirming bank may, however, choose to advise an amendment without extending its confirmation and, if so, it must inform the issuing bank without delay and inform the beneficiary in its advice.

c. The terms and conditions of the original credit (or a credit incorporating previously accepted amendments) will remain in force for the beneficiary until the beneficiary communicates its acceptance of the amendment to the bank that advised such amendment. The beneficiary should give notification of acceptance or rejection of an amendment. If the beneficiary fails to give such notification, a presentation that complies with the credit and to any not yet accepted amendment will be deemed to be notification of acceptance by the beneficiary of such amendment. As of that moment the credit will be amended.

d. A bank that advises an amendment should inform the bank from which it received the amendment of any notification of acceptance or rejection.
} 
Text of article 10 clearly defines parties to the credit as beneficiary, issuing and confirming bank without reference to applicant. In respect with advice of an amendment, article9.d of the UCP 600 provides:

"d. A bank utilizing the services of an advising bank or second advising bank to advise a credit must use the same bank to advise any amendment thereto".

\subsubsection{Practical problems}

In most cases, after receiving the beneficiary's request for amending the credit, the applicant will discuss the matter with the issuing bank. Upon agreement of the issuing bank to issue the required amendment, it will inform the advising bank and finally the beneficiary will be informed about issuance of the amendment via the advising bank. Notice of amendment might or might not include a request for beneficiary to inform the bank about his acceptance or rejection of amendment (Malek, Quest, 2009). The beneficiary is entitled to inform the bank about his dissatisfaction with an amendment or reflect his intention to be bound with original terms of the credit (UCP 600, Article 10 (a) and 10 (c) ). There is the possibility that beneficiary does not appreciate his right to object against amendment or he is not aware about the existence of such rights. The beneficiary might even assume that presentation of complying documents with THE original terms of the credit might result in dishonouring the presentation by the bank (Ficom SA v Sociedad Cadex Ltda [1980] 2 Lloyd's Rep 118 at 127; United City Merchants v Royal Bank of Canada [1979] 1 Lloyd's Rep 267 at 275). In case of bank's rejection to comply with the request of the beneficiary to modify the amendment or stick to the terms of the original contract, he has access to different remedies:

The beneficiary may consider insistence of bank on enforcement of amendment as repudiation of the credit and claim for damages from the bank. Other option would be, returning to applicant and asking for withdrawal of amendment. Where withdrawal of amendment is rejected by applicant, the beneficiary has clear cause of action against both the bank and the applicant together under the sales contract and the credit (Ellinger, Noe, 2010). The final option available to the beneficiary is presenting documents in accordance with the non-amended credit (UCP 600, Article 10 (c).

According to article 10 (c) of UCP 600, advising an amendment to the beneficiary is equal to an offer provided by the bank to him and without express acceptance of the beneficiary or his action upon amendment, it will not have any legal obligation

e. Partial acceptance of an amendment is not allowed and will be deemed to be notification of rejection of the amendment. f. A provision in an amendment to the effect that the amendment shall enter into force unless rejected by the beneficiary within a certain time shall be disregarded" 
for him. Article 10 (f) even prohibits parties to include conditionS like amendment should come into force after a certain time if it's not rejected expressly by beneficiary.

\subsubsection{Confirming bank and Amendment}

UCP stipulates that the issuing bank is legally bound to an amendment upon issuing it. Even silence of beneficiary will not relieve the issuing bank from its liability in terms of the issued amendment (UCP 600, Article 10 (b)). However, the situation is not the same for the confirming bank as it can simply advise the amendment without adding confirmation to it. Before accepting the amendment by the beneficiary, the credit remains non-amended and the bank continues its obligation as confirming the bank to it. New circumstances will come into existence where amendment is accepted by beneficiary. By then, the credit is amended and the confirming bank will be only an advising bank to it without any extra liability (UCP 600, Article 10 (b)).

\subsection{Non-conformation of the credit with the underlying contract}

Where credit conforms to terms and conditions of the underlying contract, the seller cannot object upon it (Malek, Quest, 2009). Where the credit is not conforming to the terms and conditions of the underlying contract, the beneficiary must inform the applicant about irregularities. In such circumstances, in most cases the beneficiary either rejects the credit or asks for amendments. However, there might be the situation in which the seller performs under contract of sales despite disconformity of the credit. In the english legal system, three different possibilities are considered for such situation: first, the seller might have waived the nonconformity. Second, he might be estopped from relying on irregularities. Third, it might be held that the underlying contract has been varied in conformity with the credit which is opened for the purpose of financing it (Malek, Quest, 2009) . In case of waiver or estoppel the seller can issue a notice to the buyer and require fixing of irregularities within a reasonable time. Therefore, first two situations have only "suspensory effect" on the rights of seller (Malek, Quest, 2009). However, variation of the underlying contract particularly, being supported by consideration has much border effect (Ellinger, Noe, 2010).

Under English Law, Panoutsos v. Raymond Hadley Corporation is leading case on waiver. According to the contract of sales, the buyer was supposed to provide payment in format of the confirmed documentary letter of credit in instalments. However, the credit was furnished but without confirmation. Sellers did not react and made shipments as already agreed and collected payments. Later, they cancelled the contract without giving any notice to buyers stating that the credit was not in compliance with the terms and conditions of the underlying contract. 
The Court of appeal held that despite the fact that the seller was entitled for cancelation of the contract due to non-conformance of the credit; they could do so, either before making shipments and receiving part of payment or after sending a proper notice of intention to buyers and giving them reasonable time to obtain confirmation for the credit (Panoutsos v. Raymond Hadley Corporation [1917] 2 K. B. 473.). Therefore, sellers were held not to be in position for repudiating the contract as they have already waived buyer's failure to furnish a confirmed credit (Panoutsos v. Raymond Hadley Corporation [1917] 2 K. B. 473.). ${ }^{1}$

In the framework of English law, doctrine of estoppel refers to condition under which a party to a contract is estopped from claiming a right due to representation which he has made and resulted in other's parties' reliance (Todd, 2013). In the case of Glencore Grain Rotterdom BV v Lebanese Organization for International Commerce the underlying contract covered the sale of 25,000 tons of wheat at US\$ $135 /$ ton. Additionally, the buyers agreed to pay extra US\$ 7/ ton in case of their failure to accept goods according to contract. Terms of shipment in the contract were set as FOB on a chartered vessel by buyers and payment was supposed to be made via confirmed irrevocable letter of credit. Additionally, buyers mentioned that the bill of lading should mention "freight prepaid" which got rejected by sellers. However, buyers kept their position firm and sellers did not raise any further objection. The chartered vessel had one day delay while arriving in the port of loading which resulted in refrainment of sellers to load the cargo and ask extra payment for pre-payment of freight and additional US $\$ 7$ per ton. The buyers sued the sellers and claimed for damages. However, The Court of Appeal ruling in favour of beneficiary sellers held (Glencore Grain Rotherdom BV v Lebanese Organization for International Commerce [1997]4 All ER 514.) 2: "sellers conduct was not inconsistent with their previous objection and that there had been no unequivocal representation that the sellers had relinquished or would relinquish

\footnotetext{
${ }^{1}$ In this regard, Viscount Reading CJ. observed:

"In Bentsen v. Taylor, Sons \& Co. Bowen L. J. stated the law as to waiver thus: `Did the defendants by their acts or conduct lead the plaintiff reasonably to suppose that they did not intend to treat the contract for the future as at an end, on account of the failure to perform the condition precedent?' Reading sellers for defendants and buyer for plaintiff in that passage, it applies exactly to the present case. The sellers did lead the buyer to think so, and when they intended to change that position it was incumbent on them to give reasonable notice of that intention to the buyer so as to enable him to comply with the condition which up to that time had been waived."

${ }^{2}$ Evans L. J. commented obiter that:

"What may be called the classic rules of estoppel and waiver can apply in circumstances such as these, so as to prevent a party who fails or refuses to perform the contract from relying upon conduct by the other party which would otherwise justify his doing so. The occasions when these rules may be involved in these circumstances are limited, for example, by the fact that it is rarely if ever possible to imply an unequivocal representation of fact from a party's silence on the relevant issue."
} 
their rights arising out of buyer's failure to open a conforming letter of credit" (Malek, Quest, 2009).

W. J Alan \& Co. Ltd. v. El Nasr Export and Import Co is the leading case on variation of contract resulted from conduct of beneficiary sellers. In the contract of sales for two consignmentS of Kenyan coffee to Egypt, the price was quoted in Kenyan Shilling; however, the letter of credit for financing the contract was opened in Sterling (WJAIan \& Co. Ltd. v El Nasr Export and Import Co [1972] 2 Q. B. 189.). The beneficiaries did not complain on non-conformity of the credit upon its opening, but difficulties appeared when after making shipments and before presenting documents to the bank, Sterling depreciated and sellers and tried to receive different in exchange rate by claim against buyers. In the Court of Appeal, Lord Denning MR, considered the case as a waiver.

Megaw LJ held that the case is a variation of the underlying contract as sellers have accepted offer of bank based on instructions of the applicant buyer. As a result, the bank is bound to a non-alterable credit which cannot be changed without consent of all parties involved. Therefore, currency of contract has been varied to the one in the credit WJAIan \& Co. Ltd. v El Nasr Export and Import Co [1972] 2 Q. B. 189.). Stephenson LJ held: "they (sellers) were attempting to assert a liability which, by variation or waiver, they had allowed buyers to alter" (WJAIan \& Co. Ltd. v El Nasr Export and Import Co [1972] 2 Q. B. 189.).

In conclusion, doctrine of waiver and estoppel will be effective only where stipulation of waiver or being estopped to rely on his respective rights is added to the contract by party directly benefiting from it (Todd, 2013). To differentiate waiver form variation, court will decide on facts of each case separately (Benjamin's Sale of Goods, at $\S 23-076$ pp. 1688-89). However, variation will be effective only in presence of consideration (Chitty, 2012).

\section{The buyer's rights after opening credit}

\subsection{Buyer's remedies due to presentation of forged documents by sellers}

Despite the fact that the independent principle of documentary letters of credit emphasizes on separation of the credit from the underlying contract, honouring of the credit in majority of cases does not discharge all rights of parties in the underlying contract (Bridge, 2012).

As a result, the buyer has the right to bring an action in deceit against the seller who is presenting forged documents (Famouri v Dialcord Ltd (1983) 133 NLJ 153.). In such cases, the buyer will be entitled to damages where the documents presented by the seller are nothing but "waste paper" (Benjamin's Sale of Goods, at $\S 23-090$ p. 1696). 
Alavi H. (2017)

Limits of Autonomy principle in documentary letters of credit. Perspective of English Law

5.2. Buyer's entitlement to repudiate the contract of sales due to inability of seller to tender complying presentation.

Shamsher Jute Mills v. Sehtia is the authority which provides buyer with the right to repudiate the underlying contract of sales on the occasion of sellers' failure to present required documents stipulated in the credit to bank. In this case, the seller was obliged under the irrevocable credit to tender the set of stipulated documents to bank. Upon failure of seller to present the required documents and despite conformity of goods with terms of contract the court held that such failure of seller not only prevents him from obtaining payment under the credit, but also entitles the buyer to refrain from the contract of sales and consider it repudiated.

\section{Absolute or conditional nature of the payment obligation to pay under the LC}

Since the credit is in fact a guarantee provided to the seller beneficiary by the issuing bank, it is not possible for direct tender of documents by seller to buyer applicant and request of payment to be made by him. The contract of sales in Soproma S. P. A. v. Marine \& Animal By-Products Corporation required payment to be effectuated via irrevocable letter of credit. After rejection of first presentation by the bank, the seller made the second presentation directly to the buyers though outside the time limit for presentation stipulated in the credit. Documents were rejected by buyers and in the hearing; McNair J. ruled in favour of buyers due to late presentation and invalidity of direct presentation of documents to applicant under documentary credit system (Soproma S. P. A. v. Marine \& Animal ByProducts Corporation [1966] 1 Lloyd's Rep. 367). McNair J. observed:

"It seems to me to be quite inconsistent with the express terms of a contract such as this to hold that the sellers have an alternative right to obtain payment from the buyers by presenting the documents direct to the buyers. Assuming that a letter of credit has been opened by the buyer for the opening of which the buyer would normally be required to provide the bank both with cash or some form of authority; could the seller at his option disregard the contractual letter of credit and present the documents direct to the buyer? As it seems to me, the answer must plainly be in the negative" (Soproma S.P.A. v. Marine \& Animal By-Products Corporation [1966] 1 Lloyd's Rep. 367)

In confirmation of the above judgement, it is submitted that in the course of international transactions, the privilege of effectuating payment by documentary letters of credit is an equal right shared by applicant and beneficiary. This is not a right solely available to seller which he can unilaterally waive (Todd, 2013). Providing possibility for seller to have direct approach to buyer in request for payment instead of making presentation to the bank violates applicant's rights. 
Limits of Autonomy principle in documentary letters of credit. Perspective of English Law

"Under this form of contract, as it seems to me, the buyer performs his obligation as to payment if he provides for the sellers a reliable and solvent paymaster from whom he can obtain payment-if necessary by suit-although it may well be that if the banker fails to pay by reason of his insolvency the buyer would be liable; but in such a case, as at present advised, I think that the basis of the liability must in principle be his failure to provide a proper letter of credit which involves (inter alia) that the obligee under the letter of credit is financially solvent. (This point as to the buyer's liability for the insolvency of the bank was not fully argued before me and I prefer to express no concluded opinion upon it as I understand that it may arise for decision in other cases pending in this Court.)" (Soproma S.P.A. v. Marine \& Animal By-Products Corporation [1966] 1 Lloyd's Rep. 367, at 385).

The position is confirmed in UCP 600 by preventing beneficiary from drawing draft on applicant. ${ }^{1}$

\subsection{General provisions on Absolute or conditional nature of the credit}

It might happen in practice that despite presentation of complying documents, the beneficiary seller will not be paid by the issuing bank in case of non-confirmed credit or either confirming/issuing bank in case of confirmed credit. In such situation, the seller should be able to answer the question of whether or not he has the right for recourse against applicant. In order to answer the above question properly, it is necessary to consider two other questions: firstly, what can be the main reason behind the seller's inability of getting payment from bank? And secondly, how this issue has been addressed to, in the underlying contract of sales? (Ventris, 1990)

\subsubsection{Reason for inability of seller to get payment}

Where the seller is unable to receive payment from the bank, there are two possible reasons: firstly, that the seller himself is either late in making the presentation or, the presentation does not comply with the terms and conditions of the credit. In such condition, the seller is himself in breach of contract with the issuing bank under which he has to present the compliant documents to the bank (Ventris, 1990). However, if the seller provides evidence that his complying presentation has been rejected unreasonably, then the bank will be in breach of contract. Such situation will provide the sellers with different options. On one hand he can dispose goods for sale in order to mitigate his loss and then bring an action against the bank to court. On the other hand, it is possible to appeal to the applicant buyer in claim for price of goods under the contract of sales (Ventris, 1990). General practice of

${ }^{1}$ UCP 600 , Article 6 (c): "A credit must not be issued available by a draft drawn on the applicant" 
international trade indicates that in majority of occasions, the buyer will waive discrepancy of documents and let the bank to effectuate payment to beneficiary. Such practice is supported by UCP. ${ }^{1}$

\subsubsection{Drafting payment clause in the underlying contract of sales}

Where the bank refrains from effectuating payment despite presentation of complying documents by beneficiary, it will be possible for him to refer to the underlying contract with applicant in order to find a relief (Ellinger, Noe, 2010). Such relief depends on the interpretation of the payment clause in the underlying contract which determines opening of the credit by applicant was either absolute or conditional means of payment ( W J Alan \& Co v El Nasr Export and Import Co [1972]2 Q.B. 189). At a the first glance and with reference to the autonomy principle of documentary letters of credit, it seems that payment by means of using LC is an absolute undertaking of the bank which is accepted by seller. Therefore, the seller will have no remedies in case of being left unpaid by bank despite presentation of complying document. The above presumption is correct when the seller expressly admits the absolute nature of payment by the credit which can happen for example through his requirement to open LC with a particular bank rather than the bank suggested by the applicant (Malek, Quest, 2009). Even where the court considers nature of payment by LC as absolute, there might be some possibilities for the seller to refer for payment of goods to the buyer. Namely, when buyer asks the bank not to pay he will be in breach of contract with seller. Other occasion would be the time that the buyer takes the possession of goods.

In Newman Industries Ltd v. Indo-British Industries, plaintiffs sent a generator to their buyers Govindram Brothers Ltd in India through intermediaries Indo-British Industries. Defendants required bank (after opening the credit) not to effectuate payment before presentation of a guarantee document by plaintiffs. However, such document was required neither in the underlying sales contract nor in the credit (Newman Industries Ltd v Indo-British Industries [1956] 2 Lloyd's Rep 219). In the course hearing Sellers J., mentioned: "I do not think there is any evidence to establish, or any inferences to be drawn, that the draft under the letter of credit to be taken as absolute payment. I see no reason why the plaintiffs, in the circumstances which have so unfortunately and unnecessarily arisen look to the defendants, as buyers for payment" (Newman Industries Ltd $v$ Indo-British Industries [1956] 2 Lloyd's Rep 219). The take away point from the judgment is that the court considered the possibility for entitlement of sellers to be recovered by

\footnotetext{
${ }^{1} \mathrm{UCP} 600$, Article 16 (C, iii, b): that the issuing bank is holding the documents until it receives a waiver from the applicant and agrees to accept it, or receives further instructions from the presenter prior to agreeing to accept a waiver;
} 
buyers under given circumstances (Malek, Quest, 2009). However, The Court of Appeal reversed the decision on the basis of non-conclusion of the sales agreement ([1957] 1 Lloyd's Rep 211).

In the Australian case of Saffron v Societete Miniere Cafrika, the presentation was lawfully rejected by the bank as Chromium shipped was below the minimum required tonnage under the contract and also the bill of lading was not endorsed in bank's order as pre-requirement. Sub-buyer took the possession of goods where the buyer was not paid the price. With reference to rules of negotiable instruments, the trial judge concluded that under given circumstances, LC was not supposed to be the only method of payment (Saffron v Societete Miniere Cafrika (1958)100 CLR 244). The decision was upheld by The High Court of Australia.

In regard with absolute or conditional nature of the credit, the decision of WJ AIan \& Co v EI Nasr Export and Import Co is a key authority despite the fact that observation of court regarding conditional nature of the credit is not relevant to decision and stays strictly obiter (Malek, Quest, 2009). In the course of hearing, council of defendants raised the issue that after opening, the credit has absolute nature and the seller cannot refer to buyer in case of rejection of presentation by bank. Lord Denning MR made general comments on the issue:

"When the contract of sale stipulates for payment to be made by confirmed irrevocable letter of credit, then when the letter of credit is issued and accepted by the seller, it operates as a conditional payment of the price. It does not operate as absolute payment... if the letter of credit is honoured by the bank when documents are presented to it, the debtor is discharged. If it is not honoured the debt is not discharged" (W.J.AIan \& Co v EI Nasr Export and Import Co [1972] 2 Q.B. 212.).

In Maran Road Saw Mill v .Austin Taylor Ltd, where an agent was taking the role of THE buyer, THE bank failed in effectuating payment under the credit. Anker J. of the Queen's Bank ruling in favour of seller said:

"Can it then be said that [the defendants] have discharged their contractual obligation, when, although they have established a letter of credit, payment has not been made under it? To my mind, the answer is a simple one and is in the negative. I respectfully adopt and slightly adapt the language used by Stephenson L. J. in W. J. Alan \& Co. Ltd. v. El Nasr Exhort and Import CO. The agents promised to pay by letter of credit not to provide by a letter of credit a source of payment which did not pay." (Maran RoadS awMill v. Austin Taylor Ltd [1975] 1 Lloyd's Rep. 159)

With reference to decisions of W.J Alan \& Co. Ltd. v. El Nasr Exhort and Import $C O$ and Maran Road Saw Mill v. Austin Taylor Ltd it is submitted that principles set in these cases are nothing but "rebuttable presumptions" as based on the unique 
situation in each case court is making final decision whether the credit has absolute or conditional nature (Todd, 2013).

Some authorities consider implied or express stipulation of seller in the underlying contract as a sign for absolute nature of the credit. Such satiation will arise where: seller ""stipulates for the credit to be issued by a particular bank, in such circumstances that it is to be inferred that the seller looks to that particular banker to the exclusion of the buyer" (WJAIan \& Co v EI Nasr Export and Import Co [1972] 2 Q.B. 189 at 220). In Soproma S.p.A v. Marine and Animal By-Products Corporation ([1966] 1 Lloyd's Rep 367), the judge held view that only bankruptcy of the bank will make the seller reach the buyer for payment directly ([1966] 1 Lloyd's Rep 368). With respect to, it is submitted that the applicant buyer is normally in charge with nomination of the issuing bank; therefore, the seller who has not participated in such process should not take consequences of bank's failure in honouring the credit.

In E.D. \& F.Man Ltd. v. Nigerian Sweets \& Confectionery Co.Ltd where Nigerian buyers opened an irrevocable credit with a bank in London. Buyers received the goods and paid the bank against a 90 days draft. However, the bank went insolvent and sellers claimed against buyers for payment. In hearing and in response to buyers argument on absolute nature of the credit, Anker J. held sellers entitled to ask for buyer for price (E.D. \& F.Man Ltd v. Nigerian Sweets\& Confectionery Co. Ltd [1977] 2 Lloyd's Rep. 56.). ${ }^{1}$

Finally, in Shamsher Jute Milles Ltd v Sethia (London) Ltd, sellers of FOB contract presented documents to bank after shipping goods to buyers. After rejection of presentation by bank due to discrepancy, the sellers directly claimed against buyers for contract price plus damages. The goods were not sold in Antwerp to cover costs and the seller nor the buyer benefited from the contract. In hearing, Bingham J. answered questions regarding the conditional nature of credit and entitlement of sellers to claim price from buyer as a result of the conformity of goods. He held that accepting the credit means sellers either waived their right in the underlying contract to claim payment directly from buyer or varied the contract. Therefore,

\footnotetext{
${ }^{1}$ AnkerJ.: "Mr Evans [for the buyers] sought to submit as a proposition of law, that where the identity of the bank is agreed between the parties, and not left to the choice of the buyers, it must follow that the sellers impliedly agree that the liability of the issuing bank has been accepted by them in place of that of the buyers. I do not think that this is correct. The fact that the sellers have agreed on the identity of the issuing bank is but one of the factors to be taken into account when considering whether there are circumstances from which it can be properly inferred that the sellers look to that particular bank to the exclusion of the buyer. It is in no way conclusive. In this case..., there were other circumstances which clearly supported the presumption that the letters of credit were not given as absolute payment but as conditional payment... The sellers remedy in such circumstances is to claim from the buyers either the price agreed in the contract of sale or damages for breach of their contractual promise to pay by letter of credit. "
} 
Limits of Autonomy principle in documentary letters of credit. Perspective of English Law

they are in breach of contract with buyers due to making non-compliant presentation and as a result they cannot be entitled to recover the contract price from buyers.

\subsection{The Bank's bankruptcy}

Problems will come where the issuing bank files for bankruptcy after making the presentation by seller beneficiary and before payment of draft to him. In such situation, there are two possibilities: firstly, the buyer has already paid the LC amount to the bank, and secondly, the buyer has not paid the LC price to the bank. In the first situation and where the buyer has already paid the amount due under LC to the bank and the bank goes into bankruptcy, under absolute payment term, the seller will only receive pro rate liquidation dividends which is obviously less than the contract price $(E D \&$ F Man Ltd. v Nigerian Sweets and Confectionery Co. Ltd. [1977] 2 Lloyd's Rep 50.). However, where the payment under the credit is conditional, the seller will receive the liquidation dividends from the bank and he can appeal for the rest of purchase price to buyer applicant. (ED\& F Man Ltd. v Nigerian Sweets and Confectionery Co. Ltd. [1977] 2 Lloyd's Rep 50). In such situation, the buyer has already paid the amount due under the LC to bank and he should also cover the difference between sales price and liquidation dividends for seller (ED\& F Man Ltd. v Nigerian Sweets and Confectionery Co. Ltd. [1977] 2 Lloyd's Rep 50.). Where the buyer has not paid the LC price and the bank declares bankruptcy, under absolute credit, English law will hold: "a loss to the seller equal to the difference between the sales price and the liquidating dividend. The general creditors of the bank would reap a benefit to the extent that the buyer's payment of funds to the bank prior to the bank's insolvency exceeds the pro rata liquidating dividend received by the seller as one general creditor" (Berger, 1980). However, under conditional letter of credit, the seller will have the right to appeal for LC price to the buyer applicant and as a result, none of them will face substantial loss (ED\& F Man Ltd. v Nigerian Sweets and Confectionery Co. Ltd. [1977] 2 Lloyd's Rep 50.).

\section{Conclusions}

This paper studied the limits of the autonomy principle in documentary letters of credit under the english Law. Despite the fact that according to the principle of autonomy it is globally accepted that the letter of credit is independent from the underlying contract which gives reason to its existence, the paper touched upon different areas which can question the unlimited application of the autonomy principle in the practice of international trade. The existence of such limits can be advantageous for savvy businessmen in protecting their own economic interests. Interestingly, the fact that the underling contract can affect operation of LC in 


\section{JOURNAL OF LEGAL STUDIES}

"Vasile Goldiș" Western University of Arad

numerous aspects provides guidelines for courts and arbitrators on how to solve possible disputes between parties. Such interplay between contract of sales and the credit can be found in different areas from nature of parties obligations under the credit, to effects of non-compliance of parties to terms of the credit, variations in the LC and absolute of conditional nature of the credit; these are all items which can be defined in the framework of the underlying contract based on the agreement of parties and can play a significant role in the resolution of even complicated disputes in the course of their transaction. As a result, the paper concludes the discussion with providing the parties to international trade who intend to use letters of credit as method of payment with some recommendations in better safe guarding their own interests.

Parties are recommended to include checklistS of conditions which the other side should perform under the credit and include it in their underlying contract. It is also recommended to provide flexible terms of shipment like 45-60 days from conclusion of the sales contract rather than designating a fixed date. Such provision will help both parties to have more room for performing their responsibilities. Terms of shipment and all relevant charges including insurance costs should be clarified and the party in charge of each cost should be defined. It is recommended to seller not to impose the credit to be opened by any specific bank and to require it to be advised by his own bank. Sellers are also recommended to require a confirmed letter of credit from buyers. In return, the buyers are advised to require a certificate of inspection for goods provided by an independent inspector in the underling contract. Buyers can further require procurement of bank guarantee from seller in regard with capability to perform their commitments in the underlying contract. Buyers are recommended to impose complex documentary requirements from seller in the framework of the underlying contract in order to minimise the risk of seller's fraud. Finally, buyers are advised to include the clause of sales on approval in the contract of sales in order to prevent possibility of breach of warrantee by seller.

\section{Bibliography:}

1. Alavi, H. (2015), "Autonomy Principle and Fraud Exception in Documentary Letters of Credit, a Comparative Study between United States and England". International and Comparative Law Review, Vol. 15, No. 2,45

2. Alavi, H , (2016a), Arbitration and LC Fraud Disputes: a Comparative Approach, Russian Journal of Comparative Law, Vol. (8), 2, 70

3. Alavi, H. (2016b). Documentary Letters of Credit, Legal Nature and Sources of Law. Journal of Legal Studies, 17(31), 106-121.

4. Alavi, H (2016c), Illegality as an exception to principle of autonomy in Documentary Letters of Credit; A comparative approach, Kor. UL Rev., 20, 3 
Limits of Autonomy principle in documentary letters of credit. Perspective of English Law

5. Alavi, H. (2016d). Mitigating the Risk of Fraud in Documentary Letters of Credit. Baltic Journal of European Studies, 6(1), pp.139-156

6. Alavi, H. (2016e) "documentary letters of credit, principle of strict compliance and risk of documentary discrepancy."Korea University Law Review 19. 단일호 : 3-21

7. Arkins, J. (2000). Snow White v. Frost White: The New Cold War in Banking Law?, journal ofinternational banking law, 15(2), 30-41.

8. Bridge, M. G. (2012). Benjamin's sale of goods (Vol. 11). Sweet \& Maxwell. § 23-068 p. 1685

9. Berger, S. R., 'The Effects of Issuing Bank Insolvency on Letters of Credit' 21 Harvard International Law Journal (1980)161, at. 175

10. Chitty, J. (2012). Chitty on contracts: General principles (Vol. 1). Sweet \& Maxwell. at $\S 23-034$ p 1156

11. Chorley \& Smart, (1990), Leading Cases in the Law of Banking, 6s' ed., (Sweet \& Maxwell, London,) pp. 265-268

12. Ellinger P, Neo N, (2010), The Law and Practice of Documentary Letters of Credit, 84

13. Guest. A.G., (1997), Benjamin's Sale of Goods, Fifth edition. Sweet \& Maxwell, London, n15 at $\S 23-064$ p. 1684.

14. Goode. R , (2004), Commercial Law, Penguin, 972

15. Hedley, W. (1997). Bills of exchange and bankers' documentary credits. LLP. p. 287

16. Malek. A, Quest. D, (2009), Jack. Documentary credits: the law and practice of documentary credits including standby credits, and demand guarantees, Tottle,

17. Rosenblith, R. M., 'Modifying Letters of Credit: The Rules and the Reality' ,19 Uniform Commercial Code Law Journal (1987) 245, at 246, n. 3

18. Schmitthoff, C. M., (1990), Schmitthof"s Export Trade: The Law \& Practice of International Trade 9th ed (London, Stevens \& Sons,) p. 421

19. Tiplady, D. (1989), Introduction to the Law of International Trade, London, p. 176.

20. Todd P. (2013). Bills of lading and bankers' documentary credits. Taylor \& Francis, 61

21. Ventris, FM., (1975), 'New Problems of Financing Oil Shipments' LMCLQ, p. 38 at 42

22. Ventris, F.M. (1990), Bankers' Documentary Credits,3 rd ,Lloyd's of London Press Ltd, p p. 85-86.

\section{Table of authorities:}

1. Astro Exito Navegacion SA v Chase Manhattan Bank NA [1983] 2 AC 787

2. Banque de l'Indochine et de Suez SA v JH Rayner (Mincing Lan) Ltd. [1983] Q.B. 711

3. British and Commonwealth Holdings plc v. Quadrex Holdings Inc [1989] Q. B. 842

4. Eakinv. Continental Illinois National Bank \& Trust Co. 875 F.2d 114.116. (1989).

5. ED\&FMan Ltd. v Nigerian Sweets and Confectionery Co. Ltd. [1977] 2 Lloyd's Rep 50

6. Enrico Furst \& Co. v. WE Fischer Ltd.[1960] 2 Lloyd's Rep 340.

7. Famouri v Dialcord Ltd (1983) 133 NLJ 153.

8. Ficom SA v Sociedad Cadex Ltda [1980] 2 Lloyd's Rep 118 at 127

9. Garcia v. Page \& Co Ltd (1936) [55 LI Rep 391]

10. Giddens v. Anglo African Produce Ltd (1923) 14 LI. L. Rep. 230

11. Glencore Grain Rotherdom BV v Lebanese Organization for International Commerce [1997]4 All ER 514. 
Alavi H. (2017)

Limits of Autonomy principle in documentary letters of credit. Perspective of English Law

12. Hamza Malas \&Sons v. British Imex Industries LtD (1958) 2 QB 127

13. Heisler v Anglo-dal Ltd. [1954] 2 All ER 770.

14. Ian Stach Ltd. v Baker Bosley Ltd [1958] 2 Q. B. 130

15. Knotz v. Fairclough, Dodds and Jones Ltd. [1952] 1 Lloyd's Rep 226

16. Lindsay (AE) \& Co Ltd v Cook [1953] 1 Lloyd's Rep 328,

17. Maran RoadS awMill v. Austin Taylor Ltd [1975] 1 Lloyd's Rep. 156

18. Newman Industries Ltd v Indo-British Industries [1956] 2 Lloyd's Rep 219

19. Nicolene Ltd v Simmonds [1952] 2 Lloyd's Rep 419, affd. [1953] 2 Q. B. 543

20. Panoutsos v. Raymond Hadley Corporation [1917] 2 K. B. 473.

21. Pavia \& Co. S. p. A. v. Thurmann-Nielsen [1952] 2 Q. B. 84

22. Plasticmoda S.p.A. v Davidsons (Manchester) Ltd. [1952] 1 Lloyd's Rep 537, 538

23. Saffron v Societete Miniere Cafrika (1958)100 CLR 231.

24. Shamsher Jute Milles Ltd v Sethia (London) Ltd [1987] 1 Lloyd's Rep 388.

25. Sinason-Teicher Inter-American Grain Corporation v Oilcakes and Oilseeds Trading Co. Ltd. [1954] 1

26. Sohio Supply Co. v Gatoil (USA) Inc. [1989] 1 Lloyd's Rep 588.

27. Soproma S.p.A v. Marine and Animal By-Products Corporation [1966] 1 Lloyd's Rep. 367, 386. )

28. Trans Trust S. P. R. L. v. Danubian Trading Co. Ltd [1952] 2 Q. B. 297

29. Transpetrol Ltd. v TransölO lieproduktenN ederlandB V [1989] 1 Lloyd's Rep 309.

30. United City Merchants v Royal Bank of Canada [1979] 1 Lloyd's Rep 267 at 275

31. Urquhart Lindsay \& Co. v. Eastern Bank Ltd [1922] 1 K. B. 318.

32. W J Alan \& Co v El Nasr Export and Import Co [1972]2 Q.B. 189

33. Wahbe Tamari \& Sons Ltd. v Colprogeca Sociedade Geral de Fibras, Cafes e Produtos Coloniais Lda [1969] 2 Lloyd's Rep. 18.

34. Ward Petroleum Corp. v. Federal Deposit Ins. Corp., 903 F.2d 1299 (1990). 